PREPARED FOR THE U.S. DEPARTMENT OF ENERGY, UNDER CONTRACT DE-AC02-76CH03073

PPPL-3906

PPPL-3906

UC-70

Tritium Removal from Carbon Plasma Facing Components

by

C.H. Skinner, J.P. Coad, and G. Federici

November 2003

$\left.\stackrel{M}{M}\right|_{\substack{\text { PRInCETON PLASIMA } \\ \text { PHYSICS LABORATORY }}} ^{D}$

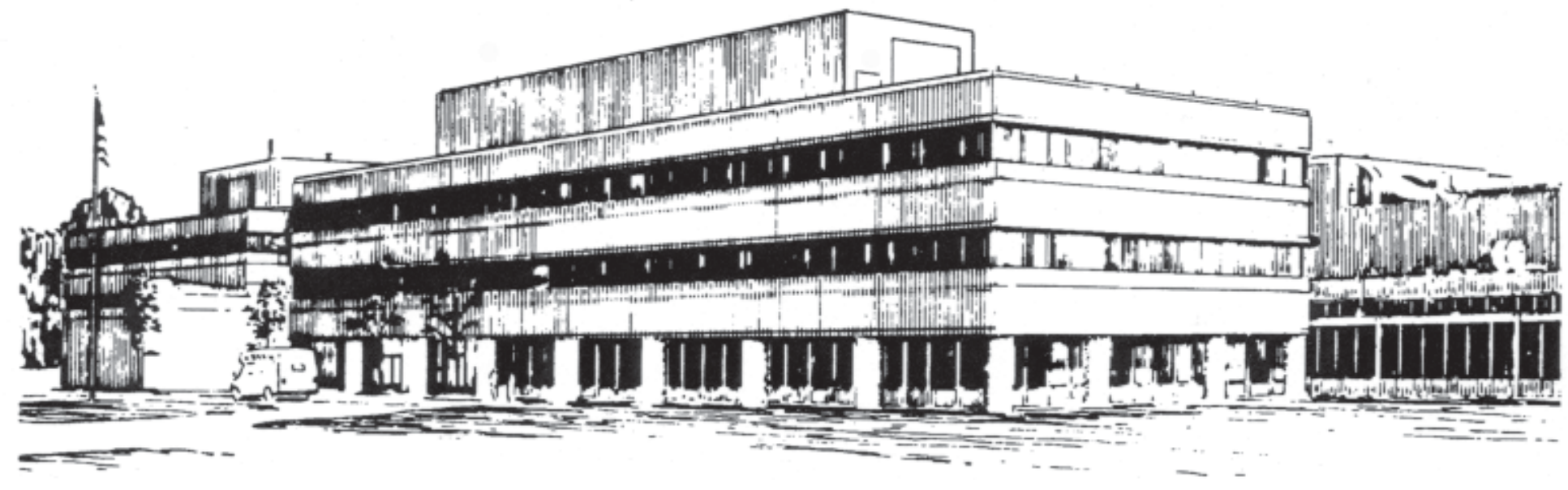

PRINCETON PLASMA PHYSICS LABORATORY PRINCETON UNIVERSITY, PRINCETON, NEW JERSEY 


\section{PPPL Reports Disclaimer}

This report was prepared as an account of work sponsored by an agency of the United States Government. Neither the United States Government nor any agency thereof, nor any of their employees, makes any warranty, express or implied, or assumes any legal liability or responsibility for the accuracy, completeness, or usefulness of any information, apparatus, product, or process disclosed, or represents that its use would not infringe privately owned rights. Reference herein to any specific commercial product, process, or service by trade name, trademark, manufacturer, or otherwise, does not necessarily constitute or imply its endorsement, recommendation, or favoring by the United States Government or any agency thereof. The views and opinions of authors expressed herein do not necessarily state or reflect those of the United States Government or any agency thereof.

\section{Availability}

This report is posted on the U.S. Department of Energy's Princeton Plasma Physics Laboratory Publications and Reports web site in Fiscal Year 2004. The home page for PPPL Reports and Publications is: http://www.pppl.gov/pub_report/

DOE and DOE Contractors can obtain copies of this report from:

U.S. Department of Energy

Office of Scientific and Technical Information

DOE Technical Information Services (DTIS)

P.O. Box 62

Oak Ridge, TN 37831

Telephone: (865) 576-8401

Fax: (865) 576-5728

Email: reports@adonis.osti.gov

This report is available to the general public from:

National Technical Information Service

U.S. Department of Commerce

5285 Port Royal Road

Springfield, VA 22161

Telephone: $1-800-553-6847$ or

(703) $605-6000$

Fax: (703) 321-8547

Internet: http://www.ntis.gov/ordering.htm 


\title{
Tritium removal from carbon plasma facing components
}

\author{
C. H. Skinner ${ }^{\mathrm{a}}$, J. P. Coad ${ }^{\mathrm{b}}$ and G. Federici ${ }^{\mathrm{c}}$
}

${ }^{a}$ Princeton Plasma Physics Laboratory, Princeton, NJ USA

${ }^{\mathrm{b}}$ JET Joint Undertaking, Abingdon, UK

${ }^{\mathrm{c}}$ ITER Garching Joint Work Site, Garching, Germany

\begin{abstract}
Tritium removal is a major unsolved development task for next step devices with carbon plasma facing components. The 2-3 order of magnitude increase in duty cycle and associated tritium accumulation rate in a next step tokamak will place unprecedented demands on tritium removal technology. The associated technical risk can be mitigated only if suitable removal techniques are demonstrated on tokamaks before the construction of a next-step device. This article reviews the history of codeposition, the tritium experience of TFTR and JET and the tritium removal rate required to support ITER's planned operational schedule. The merits and shortcomings of various tritium removal techniques are discussed with particular emphasis on oxidation and laser surface heating.
\end{abstract}

Corresponding author:

Charles Skinner email: cskinner@pppl.gov

PACS: 52.40.Hf, 52.55.Fa, 52.90.+z 


\section{Introduction}

Fast and efficient tritium removal will be essential in any next-step magnetic fusion reactor with carbon plasma facing components (PFCs). At the same time the necessary technology still needs to be established on a working tokamak, in conspicuous contrast to almost every other enabling technology, such as remote handling and superconducting magnets. This is a major unsolved development task for next-step devices with carbon PFCs. When operating with tritium fuel both the Tokamak Fusion Test Reactor (TFTR) and the Joint European Torus (JET) were able to remove sufficient tritium to stay within inventory limits, however in a next-step device the orders-of-magnitude increase in duty cycle will greatly increase the tritium accumulated per day of plasma operations while drastically decreasing the time available for its removal. Modelling for the International Thermonuclear Experimental Reactor (ITER) with carbon PFCs predicts that the in-vessel tritium inventory limit could be reached after a few weeks of DT plasma operations and tritium removal at unprecedented speed and efficiency will be required to maintain a credible plasma physics program. The magnetic and radiological environment and relative inaccessibility of parts of the divertor place severe demands on the removal technology. Simply predicting the amount and location of codeposited tritium in existing divertor machines is a challenge for state-of-the-art models. Of course, the use of tungsten PFCs would avoid this issue and tungsten is planned as an alternative for ITER if appropriate tritium removal technology cannot be demonstrated. However tungsten carries its own risks. Maintaining plasma purity with high-Z materials is a concern, and depending on the frequency and severity of ELMs and disruptions, erosion due to tungsten melt layer loss could prematurely terminate the useful lifetime of the divertor and also disrupt the planned physics program.

Extensive references on this area are available. A comprehensive review of plasma material interactions and their implications for next step tokamaks including tritium removal techniques was presented in ref. [1]. Tritium retention and removal in the two tokamaks to use tritium fuel, TFTR [2-10] and JET [11-14] has been extensively reported. Hydrogen isotope retention and recycling data is reviewed in [15]. Thermal oxidative techniques for removing hydrogen isotopes were reviewed in a paper at the $9^{\text {th }}$ Carbon workshop [16]. Detection and removal of carbon debris is described in ref. [17]. Tritium issues in ITER are reviewed in [18-22]. A survey of techniques to detritiate tiles after their removal from fusion 
machines is in refs. [23,24]. This paper will begin with a short history of hydrogen-isotope / carbon interactions in a plasma, from the successful use of graphite limiters on the Princeton Large Torus (PLT) to the experience with tritium retention in JET and TFTR. It derives the tritium removal rate required for ITER to meet its physics mission and reviews removal techniques, particularly oxidation and laser surface heating.

\section{Codeposition}

Codeposition of hydrogen isotopes with carbon is the tangible result of the interaction of plasmas with carbon PFCs. Figure 1 shows a cross section of a thick codeposit on a graphite tile from TFTR as imaged in a metallurgical microscope [25]. Carbon has a low Z and excellent mechanical properties at high temperature, ideal parameters for next step DT burning reactors; however carbon PFCs will not be acceptable without proven methods to rapidly and efficiently remove the codeposited tritium. Codeposition was not an issue in the early days of fusion research when stellarators used metal limiters. Although plasma performance advanced with the development of tokamaks, the drawbacks of using metal limiters were revealed when initial attempts to reach high temperature plasmas in PLT were stymied by the increase in core radiation from tungsten impurities [26]. Changing the limiter material from tungsten to carbon in 1978 enabled the successful attainment of low collisionality plasmas at ion temperatures of $5.5 \mathrm{keV}$ and carbon has been the favoured plasma facing material ever since.

The advantages of a carbon plasma facing surface led to the development of in-situ carbonization techniques where a carbon layer was deposited on metals by a radio-frequencyassisted DC-glow discharge technique [27]. A reduction in tritium inventory with carbonized walls as compared to stainless steel was anticipated due to lower mobility of implanted hydrogen isotopes in carbon. However, it became clear from analysis of graphite limiter tiles after the operation of the JET [28] and TFTR [29] tokamaks, that codeposition trapped hydrogen isotopes much more effectively than implantation and the amount retained could increase indefinitely without saturation. Widespread recognition of codeposition and its consequences was slow in coming. A 1984 data compendium discussed ion implantation, diffusion, reflection and desorption, but made no mention of codeposition [30]. A 1997 edition of a textbook on tokamaks [31] strangely omits codeposition from a discussion of tritium behavior in tokamaks. The ITER Physics Basis [32] mentions the need for tritium 
removal technology, but does not discuss removal methods even at a conceptual level, nor the potentially serious impact on the planned physics program of the interruptions required for tritium removal.

\section{Tritium retention in TFTR, JET and ITER.}

Fusion research attained a major milestone with the use of tritium fuel on TFTR and JET, producing 10 and $16 \mathrm{MW}$ of fusion power, respectively. In TFTR, a total of $5 \mathrm{~g}$ of tritium was injected into limiter plasmas over a 3.5 year period, mostly by neutral beam injection [33]. In JET, $35 \mathrm{~g}$ was injected into diverted plasmas over a 6 month campaign, mostly by gas puffing [34]. In TFTR the inner wall limiter provided a large source of eroded carbon and an average of $51 \%$ of the injected tritium was co-deposited on the limiter and vessel wall during plasma operations. Only a small area of the codeposit flaked off [35]. In JET, the wall is a net erosion area, and co-deposition occurred principally in shadowed parts of the inner divertor, with heavy flaking. The retention rate during the DTE1 campaign was $40 \%$. In both machines, tritium retention was initially high following a change from deuterium to tritium gas puffing, due to isotope exchange with deuterium on plasma facing surfaces (dynamic inventory). The contribution of codeposition is lower but cumulative, and is revealed by including periods of $\mathrm{D}$ fuelling that reversed the T/D isotope exchange.

The tritium retention rate varied depending on the circumstances (fueling method, history of plasma discharges, tritium inventory in the vessel etc...). For example, from the beginning of DT operations in December 1993 until August 1995, $1.9 \mathrm{~g}$ of tritium entered the TFTR torus and approximately $40 \%$ or $0.7 \mathrm{~g}$ was retained. This fraction was similar to that found in earlier deuterium retention measurements. In September 1995 L-mode discharges were fueled by gas puffing in contrast to the prior neutral beam fuelled supershots. Tritium was taken up on the previously depleted walls such that of the $1.1 \mathrm{~g}$ T supplied for these experiments, only $0.09 \mathrm{~g}$ was pumped out, a retention fraction above 90\%. After a few days the in-vessel inventory reached $1.8 \mathrm{~g} \mathrm{~T}$, close to the $2.1 \mathrm{~g}$ administrative limit and tritium removal was necessary for continued plasma operations. The internal configuration of TFTR was not changed in this period and the overall average TFTR tritium retention rate during plasma operations $(51 \%)$ was in line with the prior experience with deuterium [36] and consistent with first principles calculations $[8,9]$. 
The percentage of deuterium fuel retained in JET increased with increasing coverage of graphite wall tiles [37]. On an 'all carbon' JET, gas balance measurements show that deuterium was retained at a rate of $40 \%$ of the input, principally by codeposition [38]. Some of this was lost during venting etc. and PFC analysis showed long term retention of deuterium by codeposition at a rate of $17 \%$ of the deuterium input [39]. The introduction of beryllium PFCs increased the deuterium required to fuel the plasma by about a factor of four, but the absolute amount of retained deuterium did not increase significantly. Tritium behaviour in JET DTE1 experiments was surprisingly different from that in the earlier PTE experiments. The tritium inventory increased a factor-of-two faster than expected [12] peaking at $11.5 \mathrm{~g} \mathrm{~T}$ with more than half of the tritium on site trapped in the vessel. This increase is attributed to changes in the temperature and geometry of the divertor, although the absolute amount of tritium retained is still not quantitatively understood [40]. Pulsing in deuterium reduced the inventory to $6.2 \mathrm{~g}$ of tritium but was ineffective in reducing it further. From the PTE experience $1 \mathrm{~g}$ of tritium was expected to be retained on tiles, but measurements showed that the DTE1 levels of tritium on the tiles were lower than this. In contrast, the tritium outgassing rate was an order of magnitude higher than expected. The major difference in DTE1 was the formation of films with high $(\sim 0.8) \mathrm{D} / \mathrm{C}$ ratio on the divertor louvers and subsequent flaking and accumulation in the sub-divertor [13]. This relatively inaccessible location hampered efforts at tritium removal. An additional concern was the discovery of tritium trapped in the bulk of CFC tiles [41].

Deuterium-tritium operations are scheduled for ITER after a 3-year hydrogen phase, and 1 year of deuterium plasmas. ITER will be fuelled by approximately $120 \mathrm{~g}$ T per $400 \mathrm{~s}$ pulse and of that, 2-5 $\mathrm{g}$ T is anticipated to be trapped in the vessel, principally by codeposition with eroded carbon [19]. The in-vessel tritium inventory is limited to $350 \mathrm{~g}$ T to avoid evacuation at the site boundary in the case of the worst credible accident. Independent of safety considerations, tritium is expensive and the supply is limited so it is important to avoid inventory build up in inaccessible locations. In the worst case, the ITER in-vessel inventory limit could be reached after just one week of DT operation (Fig. 2). This estimate is tentative due to uncertainties in the chemical erosion yield of redeposited material and a lack of code validation in detached plasma regimes (in fact the same code underestimated tritium retention in JET by a factor $\mathrm{x} 40$ [40]). Retention could be higher if the ITER outer wall is a carbon deposition area [42] or if there is significant carbon erosion by type 1 ELMS [43]. On the 
other hand retention could be lower if beryllium impurities impede chemical erosion of carbon near the divertor strike points and hence tritium codeposition. However formation of mixed materials could make tritium removal more challenging. Once the tritium inventory limit is approached, DT plasma operation will be terminated and not allowed to restart until substantial amounts of tritium are removed from the vessel. The delay this entails is highly uncertain since no relevant method to remove tritium has been established on a working tokamak. Despite these uncertainties it is very clear that tritium removal at unprecedented speed and efficiency will be absolutely necessary for ITER with carbon PFCs to meet its physics mission.

\section{Tritium removal}

The scale-up in the ITER duty cycle places huge demands on any detritiation technique. ITER is envisaged to operate 2 shifts (14 hours/day), 5 days/week, 3 weeks/month, 8 months/ year with $70 \%$ availability to reach the design goal of approximately 2,000 pulses/year [44]. Each pulse is $400 \mathrm{~s}$ long and occurs every 33 minutes. The current projected tritium codeposition rate is $2-5 \mathrm{~g}$ T per pulse, principally from chemical erosion of a $20 \mathrm{~m}^{2}$ area in the divertor and would leave 50 - $125 \mathrm{~g}$ T to be removed every overnight shift! The peak codeposition rate for the ITER outer divertor is $5 \mathrm{~nm} / \mathrm{s}$ [45] and would result in a peak codeposited layer thickness growth of $50 \mu \mathrm{m} /$ day. To remove the tritiated codeposit in a routine tritium cleanup operation taking half the overnight shift a removal rate of $10 \mu \mathrm{m} / \mathrm{hr}$ is required. The ITER situation is contrasted with prior experience on TFTR and JET in Table1.

Several methods to remove tritium were investigated during the ITER engineering design activity and are reviewed in $[1,18,19]$. The methods may be grouped in two classes. One option is to break the a-C:T chemical bond either by heating to high temperatures, or by UV or chemical means such as isotope exchange. The tritium is then desorbed as $\mathrm{T}_{2}$ or DT gas and pumped out. The other option is to remove the whole codeposited layer by oxidation or by ablation with a pulsed laser or flashlamp. Potential techniques must be compatible with the 5 Tesla ambient toroidal field, as the time required to cycle the field off and on is prohibitive. It should also be compatible with the gamma field from activated components. After 20 years of operation this is estimated to be $10,000 \mathrm{~Gy} / \mathrm{h}$ at $10^{4} \mathrm{~s}$ after shutdown [46]. Demonstrations in current tokamaks are important to demonstrate that the released tritium is recoverable and there are no reactive radicals that could be reabsorbed before exiting the 
torus. Debris produced by ablative methods will need to be efficiently collected [47]. The merits and shortcomings of several techniques are listed in Table 2. Most of them have not demonstrated the $25 \mathrm{~g}$ T or $10 \mu \mathrm{m}$ codeposit removed per hour potentially required for ITER. In the remainder of this paper we focus on two techniques - oxidation and surface heating by a scanning laser.

\subsection{Hydrogen isotope removal via oxidation}

Hydrogen isotopes are released from carbon at elevated temperatures. Early laboratory experiments showed deuterium was released from both codeposited and ion implanted carbon samples on heating to $700{ }^{\circ} \mathrm{C}$ in vacuum [48], but this temperature is much higher than that of typical PFCs. Fortunately in air the release temperatures are much lower, i.e. about $300-$ $400^{\circ} \mathrm{C}$ [48]. Comparison of the effect of $\mathrm{H}_{2}, \mathrm{O}_{2}$, and $\mathrm{H}_{2} \mathrm{O}$ showed that oxygen was the most effective gas in removing deuterium [49] and the reaction mechanism was simple thermal oxidation leading to emission of $\mathrm{D}_{2} \mathrm{O}, \mathrm{CO}_{2}$ and $\mathrm{CO}$ [50]. The removal rate varied with the film structure, codeposited films from ASDEX-Upgrade being removed much faster than films grown in an RF glow-discharge [51]. Tests on codeposited films from TEXTOR showed that oxygen $(300-600 \mathrm{~Pa})$ at $250-400{ }^{\circ} \mathrm{C}$ was effective [52]. Soft films were oxidised at lower temperatures than hard films [53]. The removal rate of codeposited films on tiles removed from TFTR, JET, DIII-D and ASDEX-Upgrade ranged from $0.1-50 \mu \mathrm{m} / \mathrm{h}$ on exposure to oxygen at 250 and $350{ }^{\circ} \mathrm{C}[54,55]$ with faster erosion rates for thicker deposits (Fig. 3). The structure of codeposits is more open and porous than the underlying graphite (Fig.1) and the erosion rate for manufactured graphite is conveniently two to three orders of magnitude slower so that while the codeposit is removed and DTO released, the thickness of the graphite tile is hardly affected.

Air ventilation was very helpful in enabling TFTR and JET to control the tritium inventory. Introducing air into the room temperature TFTR torus followed by pumping released $0.2 \mathrm{~g} \mathrm{~T}$ in three cycles. This operation took 2 days for a fill at 0.99 bar, the removal rate being limited by the time required to process the tritium. At room temperature, isotope exchange plays a major role. At the end of plasma operations $0.2-0.8$ bar of air was introduced with the torus at $150{ }^{\circ} \mathrm{C}$ and $0.14 \mathrm{~g}$ T released. On JET a similar exercise removed $0.6 \mathrm{~g}$ of tritium (about $10 \%$ of the inventory). 
An important test of the efficacy of oxygen to remove hot codeposited layers and release hydrogen isotopes was performed on TEXTOR [56]. Oxygen was introduced into the torus at pressures between 0.007 and 0.3 mbar and wall temperatures between 227 and $427{ }^{\circ} \mathrm{C}$. Part of the oxygen reacted to form compounds on the wall, part reacted to produce $\mathrm{CO}$ and $\mathrm{CO}_{2}$ gases that were pumped out. Hydrogen isotopes incorporated in codeposits were released as water molecules (not as hydrogen molecules or hydrocarbons), but some of the released water was reabsorbed on the vessel walls. After oxygen exposure, He and D glow discharges were needed to restore wall conditions suitable for plasma operation and boronization was performed to reduce the oxygen impurities to the normal low levels. A quantitative estimate of the efficacy of hot oxygen to enable the pump out of hydrogen isotopes was not possible and needs more experiments and better understanding of water absorption and desorption behavior from the entire wall.

This technique can access all areas including gaps, shadowed regions and areas not in line of sight to the plasma. However there are serious obstacles. The temperature of the ITER PFCs is limited to $240{ }^{\circ} \mathrm{C}$ (the maximum temperature of the pressurized water coolant) and oxidation at this temperature is an order of magnitude slower than at $350{ }^{\circ} \mathrm{C}[54,57]$. Oxygen is known to decondition the plasma facing surfaces and a long clean-up time will be required to remove the oxygen before good plasma performance is restored. The oxygen may damage in-vessel components. The potential for mixed material effects in ITER adds further uncertainty. Tungsten [58] or boron [59] impurities were found to inhibit the oxidation of hydrocarbon films possibly through masking of the film surface. The tritium oxide produced is about 20,000 times more hazardous than elemental tritium and processing the exhaust requires a large investment in the tritium plant. For this technique to be a viable candidate more tokamak demonstrations with oxygen at the ITER conditions are clearly required, however this proposal is not looked on with favor by tokamak operators because of the known deleterious effects of oxygen on plasma performance.

\subsection{Hydrogen isotope removal by laser surface heating}

Recently a novel method for removing tritium was demonstrated. The underlying principle is robust - it is well known that tritium is thermally desorbed at high temperatures, but heating the whole tokamak to the temperature required is impractical. However most of the tritium is trapped in codeposited layers that can be heated by a rapidly scanning laser beam in vacuum 
or an inert atmosphere without the deleterious effects of oxidation [60]. Tabletop experiments with a scanning $\mathrm{Nd}$ laser have demonstrated efficient removal of tritium from JET and TFTR tile samples by this method [61,62]. A $325 \mathrm{~W}$ continuous-wave $\mathrm{Nd}$ laser beam was steered by two orthogonal mirrors and focused inside a chamber containing the tile sample. A serpentine raster pattern with line spacing $0.5 \mathrm{~mm}$ was used to cover the tile surface at a scan speed of 1 $\mathrm{m} / \mathrm{s}$ covering an area of $5 \mathrm{~cm}^{2} / \mathrm{s}$. The local duration of heating pulse was typically $1.6 \mathrm{~ms}$ and incident energy $0.2 \mathrm{MJ} / \mathrm{m}^{2}$. The surface temperature rise was much higher for codeposits than the bare tile material, because the codeposit was less thermally conductive or not in good thermal contact with the substrate [note the void spaces in the codeposit in Fig. 1]. The transiently high surface temperatures (over $2300{ }^{\circ} \mathrm{C}$ in some cases, as measured by an optical pyrometer) readily released the tritium, which was measured by an ion chamber in a closedloop circulation system. Tritium remaining after the laser scan was released by baking the codeposit in air at $500{ }^{\circ} \mathrm{C}$ for 15 mins and the efficiency of the laser detritiation derived. Fig. 4 shows the results from seven samples scanned in a variety of conditions, not all optimal. The detritiation efficiency is high, up to $87 \%$, and is the highest on the heaviest codeposits.

The atmosphere of the chamber is circulated continuously and the tritium concentration did not change after the scan indicating that reabsorption back on to the tile or isotope exchange with water on the interior chamber surface was minimal. Tritium on the inside surface of the chamber was in the 1-3 microCi range, much less than the tens of mCi typically released [61]. The codeposit remained after the temperature excursion, though the surface changed color from brownish to dark gray.

For tokamak applications the laser would remain outside the vessel and be coupled via a fiber optic to a scan head inside. Fiber optic coupling was demonstrated in the above experiments and design considerations for the application to ITER are discussed in ref. [63]. Industrial fiber optic coupled $\mathrm{Nd}$ lasers are available at powers up to $6 \mathrm{~kW}$ and the energy required to heat a 200 micron surface layer of $50 \mathrm{~m}^{2}$ area to $2,000{ }^{\circ} \mathrm{C}$ could be delivered over 3 hours. Activation will generate a strong gamma field inside ITER, however recently developed radiation resistant optical fibers have sufficient transmission. The scanner will be constructed from non-magnetic materials to be compatible with the 5 Tesla field. Novel scan head designs have been proposed to allow coverage of hard-to-access areas between tiles and in 
hidden areas. Development of prototypes and demonstrations of in-situ detritiation of a tokamak are needed but are currently unfunded.

\section{Conclusions.}

The ability of ITER to address burning plasma physics depends on the successful resolution of serious plasma material interaction issues. The change in ITER pulse length and duty cycle is larger than the change in any plasma parameter and poses severe challenges in tritium management and material erosion. Just as suitable plasma physics regimes are thoroughly explored on current tokamaks before being planned for ITER, all the candidate PFC materials for ITER should be fully tested in a large tokamak and any issues addressed with dedicated R\&D before ITER PFC procurement decisions are made. Without this step, ITER will inevitably begin operation as very expensive test bed for plasma material interactions.

Arguably the biggest technical risks in a burning plasma experiment are related to the choice of PFCs. The physics understanding of tritium retention remains incomplete and R\&D in 'housekeeping' areas such as tritium removal has not attracted support commensurate with its critical importance to ITER's mission. Tritium removal considerations should be integral to the design of the ITER divertor, and not left as an afterthought. As ITER moves toward site selection and nuclear licensing, public attitudes toward tritium and the prospective $\approx \$ 100,000$ per hour cost of unforeseen interruptions in the ITER physics program are likely to make the lack of established tritium removal technology an increasingly sensitive point in the public

support of fusion research. A scale-up of $R \& D$ effort on these issues is urgently needed to establish high-confidence solutions on tokamaks so that fusion can meet its promise as an attractive environmentally acceptable energy source for mankind.

\section{Acknowledgement}

The authors gratefully acknowledge stimulating discussions with our colleagues in this field. This work is partially funded by U.S. DOE Contract Nos. DE-AC02-76CH03073, by the UK Department of Trade and Industry, and as an account of work undertaken within the framework of ITER Transitional Arrangements (ITA). These are conducted by the Participants: Canada, China, the European Atomic Energy Community, Japan, the Russian Federation, and the USA under the auspices of the International Atomic Energy Agency. The views and opinions expressed herein do not necessarily reflect those of the Participants to the 
ITA, the IAEA or any agency thereof. Dissemination of the information in this paper is governed by the applicable terms of the former ITER-EDA Agreement. 
Table 1. Tritium parameters of TFTR, JET \& ITER.

\begin{tabular}{|c|c|c|c|}
\hline Parameter: & $\begin{array}{l}\text { TFTR } \\
\text { experience }\end{array}$ & $\begin{array}{l}\text { JET } \\
\text { experience }\end{array}$ & $\begin{array}{l}\text { ITER projections \& } \\
\text { requirements }\end{array}$ \\
\hline Tritium in-vessel inventory limit & $2 \mathrm{~g}$ & $\begin{array}{l}20 \mathrm{~g} \text { site } \\
\text { inventory }\end{array}$ & $350 \mathrm{~g}$ \\
\hline $\begin{array}{l}\text { Period of DT operation before inventory } \\
\text { limit first approached. }\end{array}$ & $\begin{array}{l}\text { Dec'93 to } \\
\text { Sept'95 or } \\
22 \text { months }\end{array}$ & $\begin{array}{l}3 \text { months left } \\
11.5 \mathrm{~g} \text { in } \\
\text { vessel }\end{array}$ & $\begin{array}{l}\approx 1 \text { week } \\
\text { (w/uncertainties) }\end{array}$ \\
\hline Typical pulse duration & $\leq 8 \mathrm{~s}$ & $30 \mathrm{~s}$ & $400 s$ \\
\hline $\begin{array}{l}\text { Cumulative DT discharge duration before } \\
\text { inventory limit first approached. }\end{array}$ & $\begin{array}{l}708 \text { pulses } \\
33 \mathrm{~min}\end{array}$ & $\begin{array}{l}500 \text { pulses } \\
250 \text { min }\end{array}$ & $\begin{array}{l}\approx 70-170 \text { pulses } \\
466-1,133 \mathrm{~min}\end{array}$ \\
\hline Time devoted to tritium removal & 1.5 months* & 3 months & $\begin{array}{l}\text { est. } \approx 5 \text { h overnight or } \\
\approx 14 \text { weekend available }\end{array}$ \\
\hline Fraction of tritium removed & $50 \%$ & $\begin{array}{l}50 \% \text { (prior to } \\
\text { venting) }\end{array}$ & Close to $100 \%$ \\
\hline Tritium removal rate & $\sim 1 \mathrm{~g} /$ month & $2 \mathrm{~g} /$ month & $\begin{array}{l}\text { Up to } 25 \mathrm{~g} T / \text { hour or } \\
10 \mu \mathrm{m} \text { codeposit / hour }\end{array}$ \\
\hline
\end{tabular}

*some of this time was devoted to other maintenance activities. 
Table 2 Techniques for tritium removal

\begin{tabular}{|c|c|c|}
\hline Technique & Merits & Shortcomings \\
\hline $\begin{array}{l}\text { Air/ } \mathrm{O}_{2} \text { exposure with } \\
\text { hot walls }\end{array}$ & $\begin{array}{l}\text { Technical simplicity, } \\
\text { access to all areas in } \\
\text { vessel. }\end{array}$ & $\begin{array}{l}\text { Removal rate insufficient at ITER design } \\
\text { temperature }\left(240{ }^{\circ} \mathrm{C}\right) \text {. } \\
\text { Wall reconditioning required to remove } \\
\text { residual oxygen and water and recover plasma } \\
\text { operation. } \\
\text { Inhibited by tungsten or boron impurities. } \\
\text { Potential for collateral damage. } \\
\text { DTO expensive to process. }\end{array}$ \\
\hline $\begin{array}{l}\text { Plasma assisted } \\
\text { oxidation via ECRH or } \\
\text { ICRH }\end{array}$ & $\begin{array}{l}\text { Does not require vent, } \\
\text { limited tokamak } \\
\text { experience, } \\
\text { compatible with } \\
\text { magnetic field. }\end{array}$ & $\begin{array}{l}\text { Removal rate insufficient especially in areas } \\
\text { not in line-of-sight to plasma } \\
\text { Wall reconditioning required. } \\
\text { Potential for collateral damage. } \\
\text { DTO expensive to process. }\end{array}$ \\
\hline $\begin{array}{l}\text { Isotope exchange with } \\
\text { D plasmas }\end{array}$ & $\begin{array}{l}\text { Simplicity, } \\
\text { effective on JET. }\end{array}$ & Removal rate inadequate for ITER \\
\hline $\begin{array}{l}\text { Divertor to include } \\
\text { 'Cold Catchers' } \\
\text { periodically heated to } \\
\text { recover tritium }\end{array}$ & & $\begin{array}{l}\text { No tokamak experience. Depends on accurate } \\
\text { predictions of location of codeposition. } \\
\text { Potential for redeposition of reactive species. }\end{array}$ \\
\hline Photo ablation & Industrial experience & $\begin{array}{l}\text { Technically difficult to apply inside ITER } \\
\text { vessel. } \\
\text { Collection of any tritiated debris required. }\end{array}$ \\
\hline Laser ablation & Laboratory experience & $\begin{array}{l}\text { Technically difficult to apply inside ITER } \\
\text { vessel. } \\
\text { Collection of any tritiated debris required. }\end{array}$ \\
\hline $\begin{array}{l}\text { Thermal desorption by } \\
\text { scanning laser }\end{array}$ & $\begin{array}{l}\text { Demonstrated on JET } \\
\text { \& TFTR samples in } \\
\text { laboratory. } \\
\text { Fast, scalable to ITER. } \\
\text { No oxygen involved. }\end{array}$ & Tokamak demonstration needed. \\
\hline
\end{tabular}




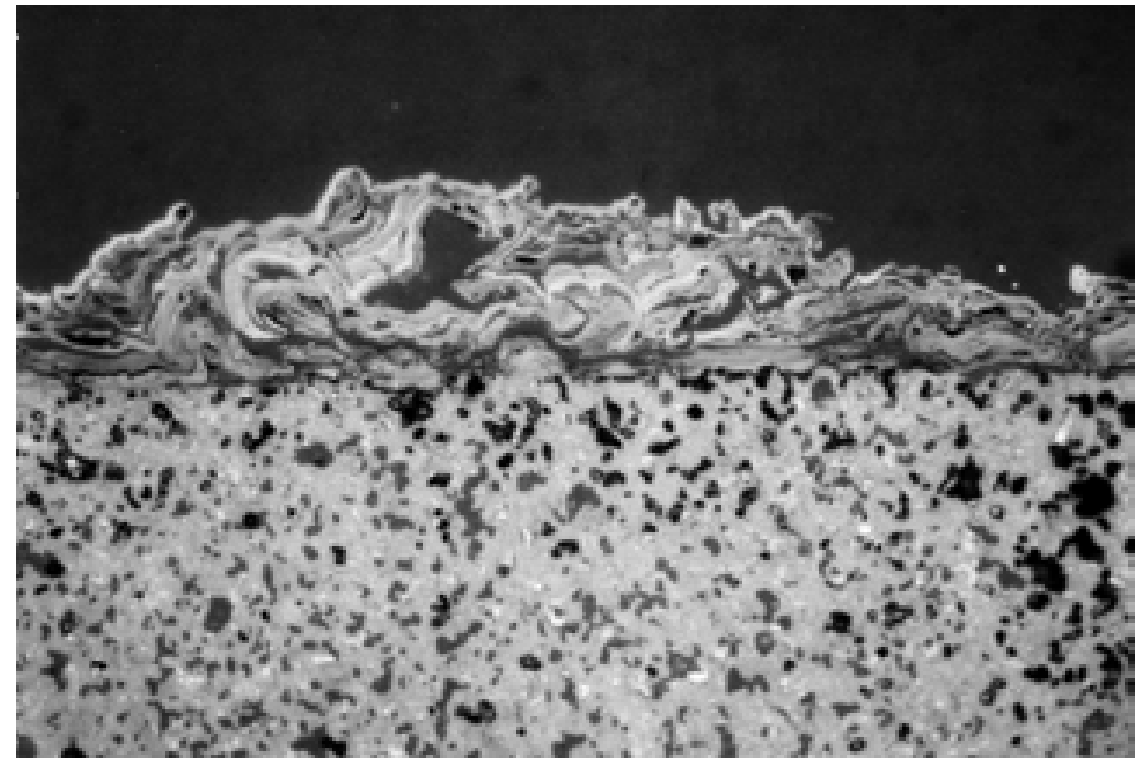

Figure 1. The cross section of a thick codeposit on a graphite tile from TFTR as imaged in a metallurgical microscope. The lower part shows the graphite of the manufactured tile, the upper irregular structure is the codeposit. The image covers 282 microns in the horizontal direction (reproduced with permission from Ref. 25). 


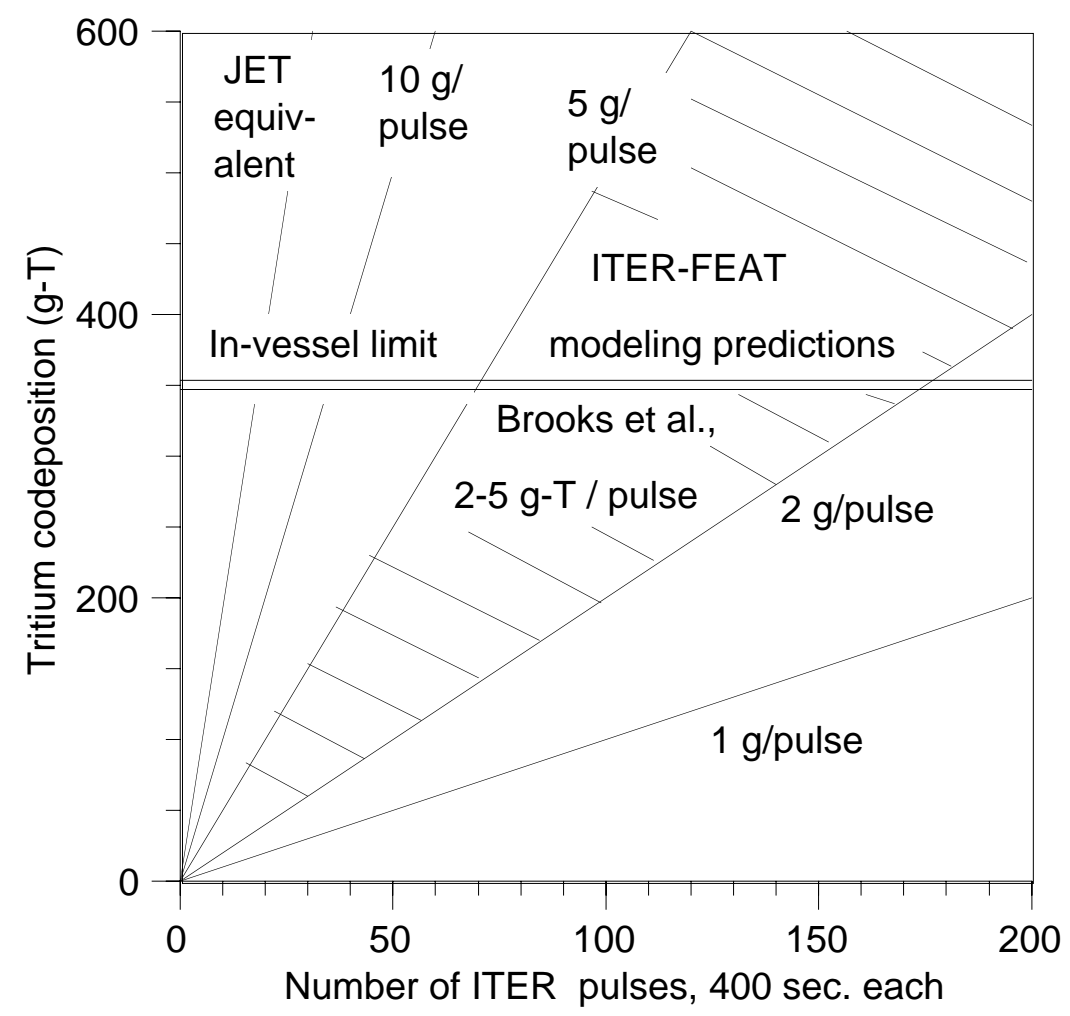

Figure 2. Tritium retention in ITER, showing modeling predictions and the JET DTE1 equivalent rate. The inventory limit (shown by double line) is predicted to be reached in approximately 100 pulses. 


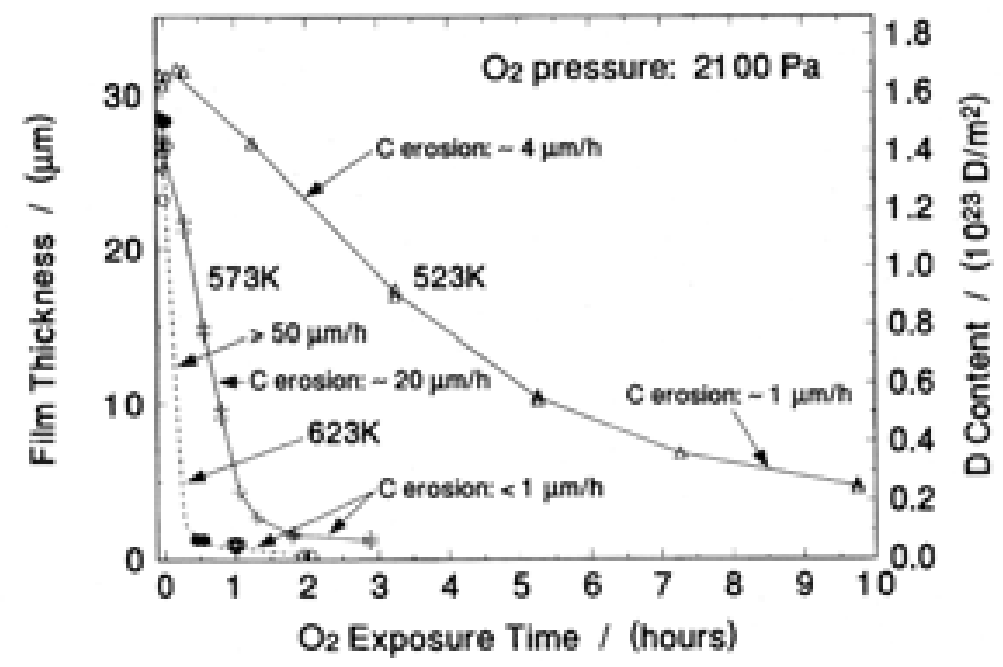

Figure 3 Film thickness as a function of $\mathrm{O}_{2}$ exposure time at 523, 573 and $623 \mathrm{~K}$ for a TFTR codeposited tile specimens, as measured by laser desorption assuming a constant $\mathrm{D} / \mathrm{C}$ ratio. Reproduced with permission from ref. [54]. 


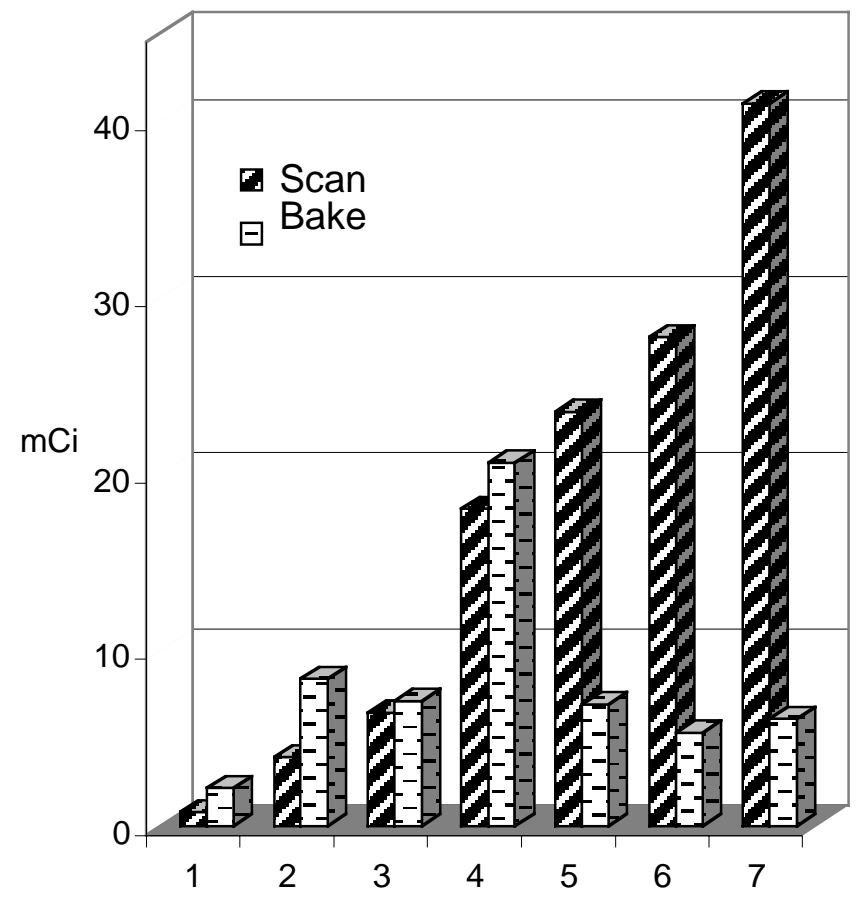

Fig. 4 Tritium released by laser scanning and the subsequent bake in air to release any remaining tritium for samples from JET and TFTR. A variety of scan conditions were used, some not yet optimal. Nonetheless the results illustrate that the detritiation efficiency is high at the locations with the highest concentrations of tritium. Reproduced with permission from ref. [62]. 


\section{References}

[1] Federici G., Skinner C. H., Brooks J. N., Coad J. P., Grisolia C., Haasz A. A., Hassanein A., Philipps V., Pitcher C. S., Roth J., Wampler W. R., Whyte D. G., Nucl. Fus., 41, 1967 (2001).

[2] Skinner C. H. et al., J. Vac. Sci. Technol. A14, 3267 (1996).

[3] Mueller D. et al., Fus. Tech., 30840 (1996).

[4] Mueller D. et al., J. Nucl., Mater., 241-243, 897 (1997).

[5] Mueller D. et al., Proceedings of the 17th IEEE/NPSS Symposium on Fusion Engineering, San Diego, October 6-10, 1997, p 279, IEEE, Piscataway, NJ, USA (1998).

[6] Nagy A. et al., Proceedings of the 17th IEEE/NPSS Symposium on Fusion Engineering, San Diego, October 6-10, 1997, p 317, IEEE, Piscataway, NJ, USA (1998).

[7] Skinner C. H., Blanchard W., Brooks J.N., Hogan J., Hosea J., Mueller D., Nagy A., Proceedings of the 20th Symposium on Fusion Technology, Marseille, Sept. 7-11, 1998 v.1, p153-156, Association EURATOM-CEA, Cadarache, France, September 1998.

[8] Skinner C. H. et al., J. Nucl. Mater., 266-269, 940 (1999).

[9] Skinner C. H. et al., J. Nucl. Mater., 290-293, 486 (2001).

[10] Skinner C. H., Gentile C.A., Young K.M., Coad J.P., Hogan J.T., Penzhorn R.-D., Bekris N., $28^{\text {th }}$ EPS Conference on Controlled Fusion and Plasma Physics

Madeira, Portugal, 18-22 ${ }^{\text {nd }}$ June, 2001 Europhysics Conference Abstracts, 25A (2001) $1621-1624$.

[11] Andrew P. et al., J. Nucl. Mater., 266-269, 153 (1999).

[12] Andrew P. et al., Fus. Eng. \& Des., 47, 233 (1999).

[13] Peacock A. T. et al., Fus. Eng. \& Des., 49-50, 745 (2000).

[14] Coad J. P. et al., J. Nucl. Mater., 290-293, 224 (2001).

[15] Causey R. A., J. Nucl. Mater., 300, 91(2002).

[16] Davis J. W. and Haasz A. A., Phys. Scripta T91, 33 (2001).

[17] Counsell G. F. and Wu C. H., Phys. Scripta T91 70 (2001). 
[18] Federici G., et al., Fus. Eng. \& Des., 39-40, 445 (1998).

[19] Federici G., et al., J. Nucl. Mater., 266-269, 14 (1999).

[20] Federici G., Brooks J. N., Iseli M. and Wu C. H., Phys. Scripta T91, 76 (2001).

[21] Federici G. and Skinner C. H., "Tritium Inventory in the materials of the ITER plasma-facing components" Springer Verlag, Berlin-Heidelberg 2002.

[22] Federici G. et al., J. Nucl. Mater., 313-316, 11 (2003).

[23] Bekris N., Caldwell-Nichols C., Doerr L, Glugla M., Penzhorn R.-D., Ziegler H., J. Nucl. Mater., 307-311,1649 (2002).

[24] Bell A. C., Williams J., Nielson J. D., and Perevezentsev A., Fus. Sci., Technol., 41, 626 (2002).

[25] Skinner C. H., Bekris N., Coad J. P., Gentile C. A., Hassanein A., Resiwig R. and Willms S., Phys. Scripta T 103, 34 (2003)

[26] Eubank H. et al., in Plasma Physics and Controlled Nuclear Fusion Research 1978 (Proc. $7^{\text {th }}$ Int. Conf. Innsbruck, 1978) Vol. 1 IAEA Vienna, p. 167 (1978).

[27] Winter. J. J. Nucl. Mater., 145-147, 131 (1989).

[28] Bergsaker H., et al., J. Nucl. Mater., 145-147, 727 (1987).

[29] Wampler W.R., et al., J. Vac. Sci. Technol. A6, 2111 (1988).

[30] Langley R. L. et al., Data Compendium for Plasma-Surface Interactions Nuclear Fusion Special Issue (1984). IAEA, Vienna 1984 p. 28.

[31] Wesson J. “Tokamaks” Clarendon Press-Oxford 1997 p. 463.

[32] Nucl. Fus., 39, 2137 (1999).

[33] Skinner C.H., Hogan J.T., Brooks J.N., Blanchard W., Budny R.V., Hosea J., Mueller D., Nagy A., Stotler D.P., J. Nucl. Mater., 266-269, 940 (1999).

[34] Andrew P. A. et al., Fus. Engin. Des. 47, 233 (1999).

[35] Skinner C. H., Gentile C.A., Menon M.M., Barry R.E., Nucl., Fus., 39, 1081 (1999).

[36] Pontau A. E., et al., Fus. Engin \& Des., 10, 365 (1989).

[37] Coad J. P., Behrish R., Bergsaker H., Eherenberg J., Emmoth B., Partridge J., Saibene G., Sartori J., Simpson J.C.B., and Wang Wen-min, J. Nucl. Mater., 162-164, 533 (1989).

[38] Sartori R., Saibene G. Tanga A., Peacock A., Pick M. and Gaze P., J. Nucl. Mater., 176\&177, 624 (1990). 
[39] Coad J. P., J. Nucl. Mater., 226, 156 (1995).

[40] Brooks J. N., Kirchner A., Whyte D. G., Ruzic D. N. and Altman D. A., J. Nucl. Mater., 313-316, 424 (2003).

[41] Penzhorn R.-D., Bekris N., Berndt U., Coad J. P., Ziegler H. and Naegele W., J. Nucl. Mater., 288, 170 (2001).

[42] Kukushkin A. S., Pacher H. D., Coster D., Pacher G. W., Reiter D., 30 ${ }^{\text {th }}$ EPS Conference on Controlled Fusion and Plasma Physics, St. Petersburg, Russia July 7$11^{\text {th }} 2003$, Europhysics Conference Abstracts.

[43] G. Federici, A. Loarte, G. Strohmayer, "Assessment of erosion of the ITER divertor targets during type I ELMs", to appear in Plasma Phys. Control. Fusion (2003).

[44] E3 Physics Operations Working Group Final Report 2002 Fusion Energy Sciences Summer Study (Snowmass 2002, unpublished).

[45] J Brooks, personal communication.

[46] H. Iida, personal communication.

[47] Delaporte Ph. Gastaud M., Marine W., Sentis M., Uteza O., Thouvenot P., Alcaraz J.L., Le Samedy J.M., Blin D., Appl. Surface Science 197-198, 826 (2002).

[48] Causey R. A., Wampler W. R. and Walsh D., J. Nucl. Mater., 176-177, 987 (1990).

[49] Chiu S. and Haasz A. A., J. Vac. Sci. Technol., A9, 747 (1991).

[50] Haasz A.A., Chiu S., Pierre J. E., and Gudimenko Y. I., J. Vac. Sci. Technol., A14, 184 (1996).

[51] Wang W., Jacob W. and Roth J., J. Nucl. Mater., 254, 66 (1997).

[52] Alberici S. Coad J. P., Hinnsen H.-K, Moormann R., Wienhold P., Wu C.H., J. Nucl. Mater., 258-263, 764 (1998).

[53] Maruyama K., Jacob W., Roth J., J. Nucl. Mater., 264, 56 (1999).

[54] Haasz A. A. and Davis J. W., J. Nucl. Mater., 256, 65 (1998).

[55] Davis J. W. and Haasz A. A., J. Nucl. Mater., 266-269, 478 (1999).

[56] Philipps V., Esser H. G., von Seggern J., Reimer H., Freisinger M., Vietzke E., Wienhold P., J. Nucl. Mater., 266-269, 386 (1999).

[57] Shu W.M., Gentile C.A., Skinner C.H., Langish S., Nishi M.F., Fus. Engin. \& Des., 61-2, 599(2002). 
[58] Davis J. W., Hamilton C. G., Haasz A. A., Macaulay-Newcombe R. G., J. Nucl. Mater., 305, 66, (2002).

[59] Davis J. W., Wright P. B., Macaulay-Newcombe R. G., Haasz A. A., Hamilton C. G., J. Nucl. Mater., 290-293, 66 (2001).

[60] Skinner C. H., Kugel H., Mueller D., Doyle B. L., and Wampler W. R., Proceedings of the 17th IEEE/NPSS Symposium on Fusion Engineering, San Diego, October 6-10, 1997, vol. 1, pp.321-324, IEEE, Piscataway, NJ, USA (1998).

[61] Skinner C. H., Gentile C. A., Carpe A., Guttadora G., Langish S., Young K. M., Shu W. M., Nakamura H., J. Nucl. Mater., 301, 98 (2002).

[62] Skinner C. H., Bekris N., Coad J. P., Gentile C. A., Glugla M., J. Nucl. Mater., 313316, 496 (2003).

[63] Skinner C. H., Gentile C. A., Guttadora G., Carpe A., Langish S., Young K. M., Nishi M., Shu W., Fusion Science and Technology 41, 716 (2002). 


\section{External Distribution}

Plasma Research Laboratory, Australian National University, Australia

Professor I.R. Jones, Flinders University, Australia

Professor João Canalle, Instituto de Fisica DEQ/IF - UERJ, Brazil

Mr. Gerson O. Ludwig, Instituto Nacional de Pesquisas, Brazil

Dr. P.H. Sakanaka, Instituto Fisica, Brazil

The Librarian, Culham Laboratory, England

Mrs. S.A. Hutchinson, JET Library, England

Professor M.N. Bussac, Ecole Polytechnique, France

Librarian, Max-Planck-Institut für Plasmaphysik, Germany

Jolan Moldvai, Reports Library, Hungarian Academy of Sciences, Central Research Institute for Physics, Hungary

Dr. P. Kaw, Institute for Plasma Research, India

Ms. P.J. Pathak, Librarian, Institute for Plasma Research, India

Ms. Clelia De Palo, Associazione EURATOM-ENEA, Italy

Dr. G. Grosso, Instituto di Fisica del Plasma, Italy

Librarian, Naka Fusion Research Establishment, JAERI, Japan

Library, Laboratory for Complex Energy Processes, Institute for Advanced Study, Kyoto University, Japan

Research Information Center, National Institute for Fusion Science, Japan

Dr. O. Mitarai, Kyushu Tokai University, Japan

Dr. Jiangang Li, Institute of Plasma Physics, Chinese Academy of Sciences, People's Republic of China

Professor Yuping Huo, School of Physical Science and Technology, People's Republic of China

Library, Academia Sinica, Institute of Plasma Physics, People's Republic of China

Librarian, Institute of Physics, Chinese Academy of Sciences, People's Republic of China

Dr. S. Mirnov, TRINITI, Troitsk, Russian Federation, Russia

Dr. V.S. Strelkov, Kurchatov Institute, Russian Federation, Russia

Professor Peter Lukac, Katedra Fyziky Plazmy MFF UK, Mlynska dolina F-2, Komenskeho Univerzita, SK-842 15 Bratislava, Slovakia

Dr. G.S. Lee, Korea Basic Science Institute, South Korea

Institute for Plasma Research, University of Maryland, USA

Librarian, Fusion Energy Division, Oak Ridge National Laboratory, USA

Librarian, Institute of Fusion Studies, University of Texas, USA

Librarian, Magnetic Fusion Program, Lawrence Livermore National Laboratory, USA

Library, General Atomics, USA

Plasma Physics Group, Fusion Energy Research Program, University of California at San Diego, USA

Plasma Physics Library, Columbia University, USA

Alkesh Punjabi, Center for Fusion Research and Training, Hampton University, USA

Dr. W.M. Stacey, Fusion Research Center, Georgia Institute of Technology, USA

Dr. John Willis, U.S. Department of Energy, Office of Fusion Energy Sciences, USA

Mr. Paul H. Wright, Indianapolis, Indiana, USA 
The Princeton Plasma Physics Laboratory is operated by Princeton University under contract with the U.S. Department of Energy.

\author{
Information Services \\ Princeton Plasma Physics Laboratory \\ P.O. Box 451 \\ Princeton, NJ 08543
}

Phone: 609-243-2750

Fax: 609-243-2751

e-mail: pppl_info@pppl.gov

Internet Address: http://www.pppl.gov 